ELORE (ISSN 1456-3010), vol. 20 - 1/2013.

Julkaisija: Suomen Kansantietouden Tutkijain Seura ry.

[http://www.elore.fi/arkisto/1_13/lindfors.pdf]

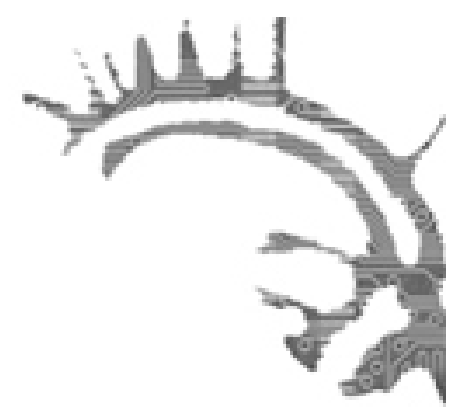

\title{
SEMINAARIRAPORTTI
}

\section{FOLKLORISTIIKAN JUHLAVA TILANNEKATSAUS}

\author{
Antti Lindfors
}

Viisas matkassa, vara laukussa - Turun yliopiston folkloristiikan professori Pekka

Hakamiehen 60-vuotisjuhlaseminaari Turussa 19.4.2013

Akateemisten juhlallisuuksien erityislaatu tiivistynee parhaimmillaan huvin ja hyödyn tasapainoiseen liitokseen. Näin myös Turun yliopiston folkloristiikan professorin Pekka Hakamiehen 60-vuotisjuhlaseminaarissa, jossa kahvin ja laulun lomassa kuultiin kolme korkea-arvoista puheenvuoroa siitä itsestään: folkloristiikan oppiaineen tämänhetkisestä tilanteesta, asemasta ja itseymmärryksestä.

Olin havaitsevinani puhujien valinnassa ja esiintymisjärjestyksessä heijastuksen Hakamiehen tutkijantaipaleen kolmesta kiintopisteestä: Helsingin (Tuomas M. S. Lehtonen), Joensuun (Seppo Knuuttila) ja viimeisimpänä Turun (Anne Heimo) yliopistokaupungeista. Matti Kuusen oppilaana pääkaupungista maisteriksi valmistunut ja 22 vuotta Joensuussa (mm. Karjalan tutkimuslaitoksessa) viihtynyt Hakamies saapui Turkuun vuonna 2006. Seminaarin avaussanoissa esimiestään empiirikoksi luonnehtinut yliopisto-opettaja FT Pasi Enges kiitteli Hakamiestä tieteellisestä avarakatseisuudesta ja toi esiin myös tämän taipumuksen hakeutua moninaisten luottamustehtävien pariin. Tarkemmin niin Hakamiehen tutkija- kuin henkilökuvastakin voi lukea seminaarissa paljastetusta Pekan juhlakirjasta, artikkelikokoelmasta Viisas matkassa, vara laukussa. Näkökulmia kansanperinteen tutkimukseen (Hovi et al. 2013). 
Silmäys iltapäivän esitelmäotsikoihin antoi osviittaa aihepiirien perustavanlaatuisuudesta: miten folkloristi käsitteellistää ja tulkitsee kohdettaan, millaisia valmiuksia hänellä on internetsisältöjen analyysiin, mitä on folkloristiikka? Suorasanaista vastausta viimeksi mainittuun ydinkysymykseen SKS:n pääsihteeri Tuomas M. S. Lehtonen ei antanut, mutta loi siihen historioitsijan näkövinkkelistään tervetulleen, tuoreen katsauksen. Huomiota herätti etenkin hänen suomalaisilta folkloristeilta kokoama, oppialan kanonisia keskeistekstejä koskeva empiirinen aineistonsa ja siitä vedetyt johtopäätökset. Yhteensä 25 perinteentutkijalta kerättyjen lausuntojen ja niiden tulosten kirjavan hajonnan (vastauksissa annettiin jopa 51 nimeä) perusteella Lehtonen päätyi luonnehtimaan kotimaista folkloristiikkaa eläväiseksi ja ainutlaatuisen epähierarkkiseksi tiedeyhteisöksi. Vahvaa kotimaista painotusta - Richard Bauman oli kärkijoukon ainoa ulkomaalainen nimi - hän tulkitsi osoitukseksi tieteenalan hyvästä itsetunnosta, mutta myös maamme edelleen korkeasta kansainvälisestä asemasta alalla (väitteelle oli muitakin perusteluja). Toivoa sopii, että kiinnostavasta kyselyaineistosta ja vastauksiin mahdollisesti liitetyistä perusteluista saadaan lukea vielä tarkemmin paperiltakin.

Kyselyn järjestämiseen Lehtosta oli muun ohessa motivoinut tieteenalalla 1990-luvun lopulta (jälleen) yleistyneet, pessimistisesti sävyttyneet kriisipuheet, jollaisilla on toki folkloristiikassa muutenkin ollut poikkeuksellisen vahva historiansa. Hän tähdensi kriisidiskurssin painottuneen englanninkielisten maiden suuntiin, vaikka nostikin esiin mainintoja myös omista oloistamme. Eetosta vastaan tosin puhuu täkäläisittäin se tosiasia, että 2000-luvun alku on Lehtosen laskujen mukaan tuottanut meillä useampia alan väitöskirjoja kuin yksikään aiempi vuosikymmen.

Tieteenalan institutionaalisen profilin, kanonisten tekstien ja niiden substanssin etupäässä folkloren määritelmien - ohella viimeiseksi lähestymistavakseen folkloristiikan erityisluonteen hahmottamiseksi Lehtonen nimesi metodologisen eklektismin. Tätä hän valotti pääasiassa Itämeren ympäristön suullisen ja kirjallisen kulttuurin vuorovaikutusta keski- ja uuden ajan taitteessa koskevan uuden tutkimusprojektinsa ja sen kahden keskeislähteen, Daavidin psalttarin ja uskonpuhdistaja Jacobus Finnon vuoden 1583 virsikirjan avulla. Virsikirjan historiallisena lähteenä ainutlaatuista johdantoa muun muuassa Finnon poeettisten ihanteiden kannalta eritellyt Lehtonen näytti, kuinka folkloristiset näkökulmat taipuvat oikeiden aineistojen yhteydessä tuottoisaan keskusteluyhteyteen musikologian ja aate- ja sosiaalihistorian intressien kanssa. Reformaation kirjallisen ja liturgisen elämän sekä uudistuneen laulukulttuurin monisuuntaisesta vuorovaikutuksesta esiin nousi etenkin runomuodon määräävyys sisältöjen kannalta. Tuloksista folkloristisesti kiinnostavimpia tullee olemaan esimerkiksi runouden välittämän kollektiivisen uskomusjärjestelmän (myyttisten viittauskohteiden) hienovaraiset muutokset muotoa koskevissa uudistuspaineissa.

Omien sanojensa mukaan ensimmäistä kertaa julkisesti paremiologina esiintynyt Seppo Knuuttila siirsi aihealueen kertaheitolla Pekka Hakamiehen omimmalle kentälle. Itä-Suomen yliopiston tuore emeritusprofessori oli valinnut sananparsistosta teemakseen ajankohtaiset kiireen ja kiireettömyyden dynamiikkaa koskevat käsitykset, joita kehystämään hän sovitti esityksensä kantavat metodologiset teemat, folkloristisen teorianmuodostuksen ja aineistokonseption. Esityksen Matti Kuusen nimeämää paradoksia mukaileva johtokysymys kuului, kuinka suullista perinnettä - aiemmin vallin- 
neita käsityksiä, kokemuksia, tunteita - luetaan sinänsä muuttumattomista kirjallisista lähteistä, joita siis paradoksin mukaan on käsitysten ikään nähden suhteettoman suuri määrä varsin myöhäisinä tallenteina.

Knuuttila pohjusti sananparsianalyysiään kontekstualisoimalla ensin kahden paremiologimme, Kuusen ja Hakamiehen tieto-opilliset sitoumukset oppihistoriallisesti omiin ajankohtiinsa. Siinä missä Knuuttilan mukaan propositionaaliseen (ks. Knuuttila 1992, 37-39) maailmankuva- ja tietokäsitykseen nojautuneen Kuusen suhde sananparsista tulkittavaan kansanluonteeseen oli kielteinen (Kuusi 1952: "mitään yhtenäistä koko kansan etiikkaa [...] ei ole koskaan ollut olemassa") tai suopeimmillaan ambivalentti, Hakamiehen joustavammassa kognitioteoreettisessa lähestymistavassa etualalle asettuu aina kontekstin ja näkökulman yksityiskohtaisempi todistusvoima. Toisin sanoen sananlaskut kyllä välittävät ja uusintavat perustavia käsityksiä kulttuurin kognitiivisista kategorioista, mutta tekevät sen tilannekohtaisesti ja tilapäisesti, eivät mitään pysyvää ja yhtenäistä näkemystä kuvastellen. Eri tietoainekset ja tulkintakehykset aktivoituvat eri yhteyksissä erilaisin motivaatioin, ja ihmismielen kyky sietää sisäisesti ristiriitaisiakin käsityksiä on tunnetusti ilmiömäinen.

Eriaikaisia kiirekäsityksiä ja kiireen kokemuksellista muutosta arvioidessaan Knuuttila itse oli ottanut ohjenuorakseen juuri monimerkityksellisyyden korostamisen, ei sen tukahduttamisen. Hän aloitti huomauttamalla kiirepuheenkin (vrt. kriisipuhe) kantavan menneisyyteen suuntautuvia romanttisia tendenssejä, aivan kuin kiireestä ei ennen olisi kärsitty ja leppoisaa joutenoloa olisi sen sijaan arvostettu hyveenä. Vanhojen kiireestä varoittelevien kieltosananparsien edessä olisikin nyt houkuttelevaa tulkita niiden puhuvan juuri tätä perspektiiviharhaa vastaan. Yhtä hyvin voidaan kuitenkin hypätä itse aineistojen matkaan ja kysyä, mitä ennen tarkkaan ottaen opastettiin välttämään, mikäli kiirettä ahdistavana "hetken tyranniana" (Eriksen 2003) ei ikään kuin olisi tunnettu. Puhummeko edeltävien sukupolviemme kanssa lainkaan samaa kieltä?

Aiemmin yleisempää käytäntöä tapaillen Knuuttila oli etsinyt aiheelleen virikkeitä nimenomaan kielitieteellisistä löydöksistä. Lauri Hakulisen 1930-40-lukujen etymologisiin selvityksiin nojautuen hän sitoi vanhan kansan kiirekäsityksen tulen, poltteen ja hekuman merkitysympäristöihin ja avasi tätä kautta näkökulman ensi tuntumalta yllättäville intohimon ja seksuaalisuuden sektoreille. Kiire huippuna tai lakena ("kiireestä kantapäähän”) puolestaan vahvistaisi entisestään sanan vaarallisiksikin koettuja konnotaatioita ja näihin yhteisöllisesti kohdistettuja säätelypyrkimyksiä. Merkillepantavaa on mielestäni myös se, kuinka seksuaalisuutta olisi näissäkin yhteyksissä näytetty projisoidun nimenomaan naiseen: "kirki piiassa palaapi, kirki piian kintahassa". Vauhdikkaasti edennyt puheenvuoro tarjosi kuulijoille runsaasti sulateltavaa ja jätti tilaa myös tarkennuksille ja lisäkysymyksille - Knuuttilan tuore artikkeli aiheestaan onkin löydettävissä aiemmin mainitusta Hakamiehen juhlakirjasta.

Kolmantena esiintynyt Suomen Akatemian tutkijatohtorina työskentelevä Anne Heimo rikastutti iltapäivän kuluessa hahmottunutta folklorekonseptiota kohdistamalla katseensa verkkoympäristöön ja valaisemalla sitä perinteen uusien muotojen ja elämien alustana. Kriisipuheista uloskäynnin melkeinpä ohimennen muotoilleen esityksen motiivina oli paitsi esitellä netistä tunnistettavia folkloristisia tutkimuskohteita myös puolustaa perinteentutkimuksen näkökulmien kelpoisuutta uudistuvan, digitaalisen 
arjen haltuunotossa. Vaikka asia tuoreita opiskelijoiden opinnäytetöitä vilkaisemalla näyttäytyisikin varmasti toisenlaisena, on totta, että folkloristiikan julkaisuissa internetperinne on viime vuosiin saakka noussut vain satunnaisintressinä näkyviin. Näin siis tieteenalalla, joka on vanhastaan (ja oikeutetusti) voinut ylpeillä sekä metodologisen että substantiaalisen kaikkiruokaisuuden traditioillaan.

Heimon ensimmäisenä esittelemä työväline, Richard Dawkinsilta periytyvä ja sittemmin nettijargoniin omittu meemin käsite teki esityksen edetessä nopeasti tietä yhä eksoottisemmille tulokkaille. Sosiaalisen median variaatiot ja muut uusien kommunikaatiovälineiden ja -alustojen tuottamat käytännöt ovat ilmiselvästi herättäneet folkloristeissa jälleen intoa terminologiseen innovointiin: netistä on perinteentutkijan silmin tunnistettavissa niin uutis- ja photoshoplorea, remixejä, kliktivismia (verkon kevytaktivismia) kuin perinteisempiä vastakulttuurisia muotojakin. Nähtäväksi jää, monellako käsitteistä on pysyvämpää kantavuutta ja monenko kohtalona on haipua oppihistorian välilehdille (vrt. faxloreen ja xeroxloreen, mutta myös poploreen). Heimo itse on jo pidemmän aikaa kannattanut erityisesti kliktivismiä niin käsitteenä kuin vakavasti otettavana toimintamuotonakin, jonka painoarvoa on esimerkiksi viimeaikaisten verkossa mobilisoitujen kansalaisaloitteiden suosion valossa yhä vaikeampi täysin kiistää.

Puhujalle itselleen läheisimmät tutkimusintressit, (virtuaalisen) muistin, muistitiedon ja menneisyyden kysymykset jäivät esityksessä ehkä sivurooliin, mutta kytkeytyivät sinänsä oivasti uusien kulttuuristen käytäntöjen tunnistamisen teemaan ja vastaavasti tutkijan tarpeeseen tarkistaa omia aineistokäsityksiä ja teoreettisia näkökulmiaan. Kiinnostavia edistysaskeleita otetaan esimerkiksi niillä suunnilla, missä nettiä analysoidaan elokuvien tavoin tehokkaana muistin teknologiana, joka performatiivisuudessaan ylittää vaivatta yksityisen/julkisen ja yksilöllisen/kollektiivisen kaltaisia dualismeja.

Sikäli kun internetaineistojen analyysiä ainakin Suomessa edistävät yhä tehokkaimmin etupäässä yhteiskuntatieteiden ja mediatutkimuksen edustajat, folkloristien tulisi mitä pikimmin määritellä oma suhteensa tähän jo joiltain suunnilta valaistuun kenttään. Mielestäni kysymystä folkloristin erityisosaamisesta nettisisältöjen yhteydessä on luontevaa lähestyä itse perinteen määritelmistä käsin. Tässä suhteessa hyvän lähtökohdan muodostaa esimerkiksi Heimon siteeraaman Trevor J. Blankin digiperinnettä ajatellen muotoiltu näkemys folkloresta "yksilöiden ja heidän yhteisöjensä moninaisessa vuorovaikutuksessa, moninaisina muotoina ilmenevinä luovuuden ilmauksina". Blankin määritelmä istuu ensinnäkin hyvin eriaikaisten perinnekäsitysten jatkumoon, ja sitä on toisekseen helppo täydentää esimerkiksi Tuomas M. S. Lehtosen katsauksessaan painottamilla folklorekäytäntöjen määrämuotoisuutta ja kaavoittuneisuutta koskevilla kriteereillä. Viime kädessä onkin nähdäkseni vain rohkaisevaa havaita perinteen jäsentyvän netin aikakaudellakin luovan variaation, kollektiivisuuden ja kansanomaisuuden - ei siis välttämättä traditionaalisuuden tai suullisuuden (ks. Blank 2009) - lähtökohdille.

Visaisten esimerkkitapausten - tuottavatko netin meemigeneraattorit folklorea? - ja muidenkin innostavien sitaattien koristelema puhe päätti seminaarin kaiken kaikkiaan optimistisiin äänenpainoihin. Ennen juhlakalulle osoitettuja virallisia tervehdyksiä estradin valtasi vielä ainejärjestö NEFA:n jäsenistön alkuaan perustama Äimän Käet -kuoro.

Onnittelut vielä kerran Pekalle! 
Antti Lindfors: Folkloristiikan juhlava tilannekatsaus

\section{KiRJALlisuUs:}

Blank, Trevor J. 2009: Toward a Conceptual Framework for the Study of Folklore and the Internet. - Blank, Trevor J. (ed.), Folklore and the Internet. Vernacular Expression in a Digital World. Logan, Utah: Utah State University Press.

Eriksen, Thomas Hylland 2003: Hetken tyrannia. Helsinki: Johnny Kniga.

Hovi, Tuomas, Hänninen, Kirsi, Leppälahti, Merja \& Vasenkari, Maria (toim.) 2013: Viisas matkassa, vara laukussa. Näkökulmia kansanperinteen tutkimukseen. Turku: Turun yliopisto.

Knuuttila, Seppo 1992: Kansanbuumorin mieli. Kaskut maailmankuvan aineksena. Helsinki: SKS.

Kuusi, Matti 1952: Esivanhempiemme kymmenen käskyä. - Kalevalaseuran vuosikirja 32. Porvoo ja Helsinki: WSOY.

Kirjoittaja on folkloristiikan jatko-opiskelija Turun yliopistossa. 